\title{
Palynology of some Danish glacial sediments
}

JENS MORTEN HANSEN

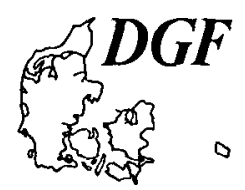

Hansen, J. M.: Palynology of some Danish glacial sediments. Bull. geol. Soc. Denmark, vol. 28 pp. 131-134, Copenhagen, February 22nd, 1980. https://doi.org/10.37570/bgsd-1979-28-16

Samples of Danish glacial sediments have been analysed for palynomorphs. It is shown that the majority of dinoflagellates and acritarchs are reworked from the pre-Quaternary subground. On the basis of an approximate stratigraphic grouping of the palynomophs, the microplankton content can be divided in a parautochtonous and an allochtonous group relative to the local pre-Quaternary subground. Thus, the matrix of the glacial deposits appears to have been transported considerably shorter than the clasts. This indicates that the majority of clasts in Danish tills has been transported during several cycles of reworking and deposition.

Jens Morten Hansen, Geological Survey of Denmark, Thoravej 31, DK-2400 København, Denmark. November 10th, 1979.

The present study is a brief survey of the palynology of some till-sediments from the kineto-stratigraphical scheme of the Danish Weichselian (cf. Berthelsen, 1978 for references). Samples have been processed using standard palynological preparation techniques as modified by Hansen \& Gudmundsson (in press). All samples yielded rich palyno-assemblages and were particularily rich in Upper Cretaceous and Cenozoic dinoflagellates, Mesozoic and Cenozoic spore-pollen, Lower Palaeozoic acritarchs and the green alga Pediastrum.

Palynological studies on Danish glacial material have previously been carried out by Andersen (1965) on the basis of material from Lindø. However, Andersen's study was based mainly on the spore-pollen content and lead to the conclusion that palynological studies applied to glacial sediments would be of limited stratigraphic value. By contrast the present study emphasizes the plankton content, which in most preparations constitutes the major part of the palynoassemblage.

\section{Subdivision of the palyno-assemblages}

Since the palyno-assemblages in Danish tills may cover a stratigraphic column from the Precambrian to the Quaternary it is mandatory to group the palynomorphs in operational groups. These groups must not be defined in such a way that knowledge at specific level to all taxa from the Precambrian to the Quaternary is required. However, a meaningful grouping cannot be based on general morphological criteria only. Therefore, it is attempted to group the palynomorphs with reference to broadly defined stratigraphic levels, to especially characteristic taxa and to characteristic morphological groups. Using these 3 criteria 10 groups are distinguished:

1) Spore-pollen. All spore-pollen grains.

2) Pediastrum. This group contain exclusively the green alga Pediastrum.

3) Acritarchs. Mainly Lower Palaeozoic (Ordovician - Silurian) genera e.g. Baltisphaeridium, Veryhachium, Orthosphaeridium, Micrhystridium.

4) Wetzeliella. This group is exclusively composed of the predominantly Eocene (Upper Paleocene - Oligocene) genus Wetzeliella s.l.

5) Mesozoic - Cenozoic chorate dinoflagellates. All Mesozoic - Cenozoic spinose dinoflagellates, which cannot be placed in group 6 and 7 .

6) Upper Cretaceous - Lower Danian chorate dinoflagellates. All spinose dinoflagellates, which in Denmark preferrently occur in Upper Cretaceous - Lower Danian sediments.

7) Upper Danian - Oligocene chorate dinoflagellates. All spinose dinoflagellates, which in Denmark preferently occur in Upper Danian Oligocene sediments.

8) Proximate dinoflagellates. Dinoflagellates with 
no central body and without spines. Most specimens probably originate from MaastrichtianDanian sediments.

9) Cavate dinoflagellates. Forms with clearly separated peri- and endophragma (excl. Wetzeliella). Most specimens probably originate from Upper Cretaceous sediments.

10) Others. Various palynomorphs, which cannot be placed in groups 1-9, e.g. fossil fungi, algae, genera like Tasmanites, Leiofusa and severely damaged dinoflagellates.

\section{Samples}

Samples were kindly provided by Michael Houmark-Nielsen. The 12 samples were labeled:

Sample 1: Bluish grey till, Kulhuse, Northern Sjælland, MH 9.

Sample 2: Bluish grey till, Tulstrup, Northern Sjælland, MH 16.

Sample 3: Bluish grey till, Vesterløkke, Samsø, V 2.

Sample 4: Bluish grey till Ebbeløkke, Sjællands Odde, E 2.

Sample 5: Brown till, Orø, Isefjord, MH 15.

Sample 6: Brown till, Lyngerup, Isefjord, MH 14. Sample 7: Brown till, Lyngerup, Isefjord, MH 13. Sample 8: Brown till, Lyngerup, Isefjord, MH 12. Sample 9: Brown till, Sejrby, Sejrø, MH 11.

Sample 10: Brown till, Als, MH 10.

Sample 11: Older Yoldia Clay, Frederikshavn.

Sample 12: Younger Yoldia Clay, Frederikshavn.

According to kineto-stratigraphical concepts as outlined in Berthelsen (1978) the samples 1-4 belong to the so-called »NE-ice «, samples 5-8 to a young Baltic ice (the so-called $» S E-i c e \ll$ ), samples 9-10 to an older Baltic ice (Michael Houmark-Nielsen 1977: pers. comm.) while samples 11-12 belong to glacio-marine deposits from the middle and late Weichselian respectively.

\section{Results}

On the basis of the palynological content the 12 samples can be placed in 4 different categories:

A) Samples: 1, 2, 3. Spore-pollen dominates, a large proportion seems to be Quaternary; small quantities of Pediastrum, acritarchs and Wet- zeliella. Dinoflagellate groups 5 and 6 dominate the dinoflagellate content, while group 7 is represented in small quantities.

B) Samples: 4, 5, 6, 7, 8. Dinoflagellate group 7 (mainly Paleocene) dominates the palynoassemblage completely. The spore-pollen content is mainly of pre-Quaternary origin. Lower
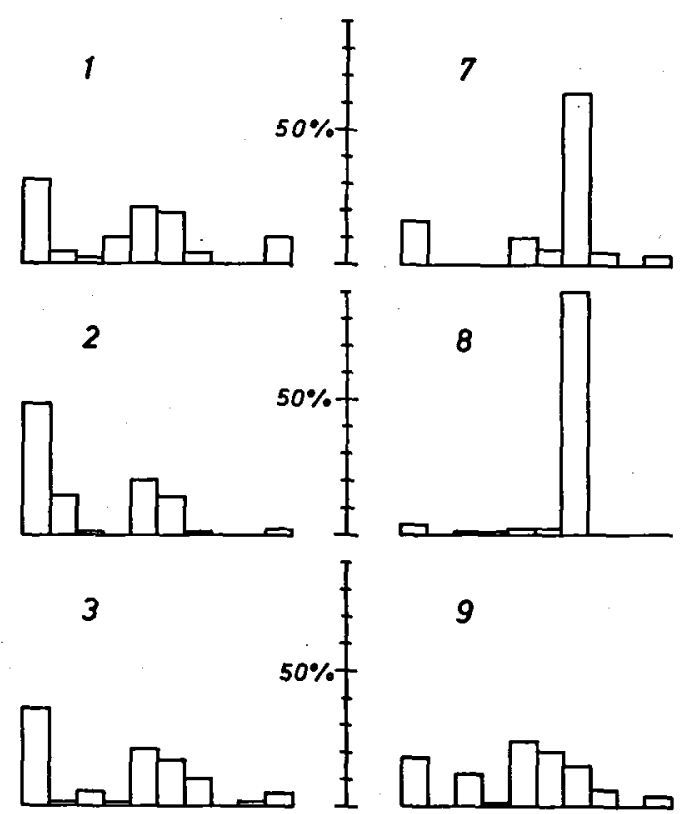

4

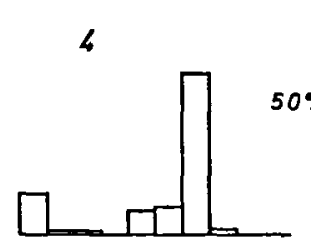

10

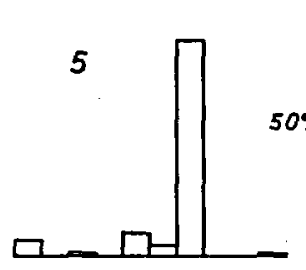

6

6
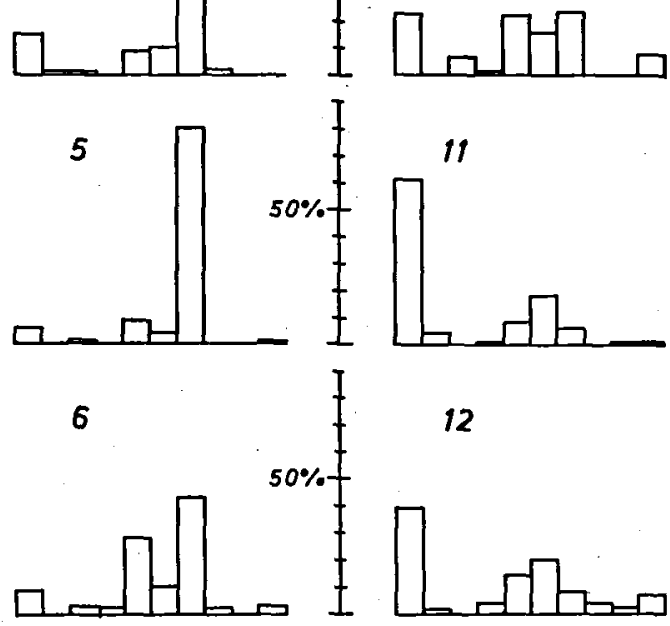

11

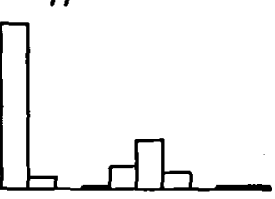

12

Fig. 1. The palynomorph content in samples 1-12. From the left to the right the columns represent groups $1-10$. 
Palaeozoic acritarchs may be present in very small quantities.

C) Samples: 9, 10. Dinoflagellate group 5, 6, 7 dominate. Lower Palaeozoic acritarchs present in relatively high quantities. Wetzeliella (Eocene) precent. Spore-pollen content is mainly of preQuaternary age.

D) Samples: 11, 12. Allmost like category A, but Lower Palaeozoic acritarchs are missing. A small proportion of the dinoflagellates are of Quaternary origin.

Between 100 and 400 palynomorphs per sample have been identified to generic level, and when necessary to specific level (fig. 1).

\section{Discussion and conclusion}

The high biostratigraphic resolution obtained through dinoflagellate zonations may to some extend allow a determination of the age of the strata from which the dinoflagellate and acritarch content is derived. This determination, combined with the pre-Quaternary geological map of Denmark, offers the possibility of evaluating how far the glacial matrix material has been transported. For that purpose the plankton content has been subdivided into allochtonous microplankton, parautochtonous microplankton and stratigraphically insignificant microplankton (fig. 2).

The allochtonous group is defined as that part of the microplankton content that has been transported more than $10 \mathrm{~km}$, i.e. the allochtonous microplankton species are not present in the pre-Quaternary subground of the area within a distance of $10 \mathrm{~km}$. The parautachtonous group is defined as that part of the microplankton content that may have been transported less than $10 \mathrm{~km}$, i.e. the parautochtonous microplankton content is probably present in the pre-Quaternary subground of the area within a distance of $10 \mathrm{~km}$.

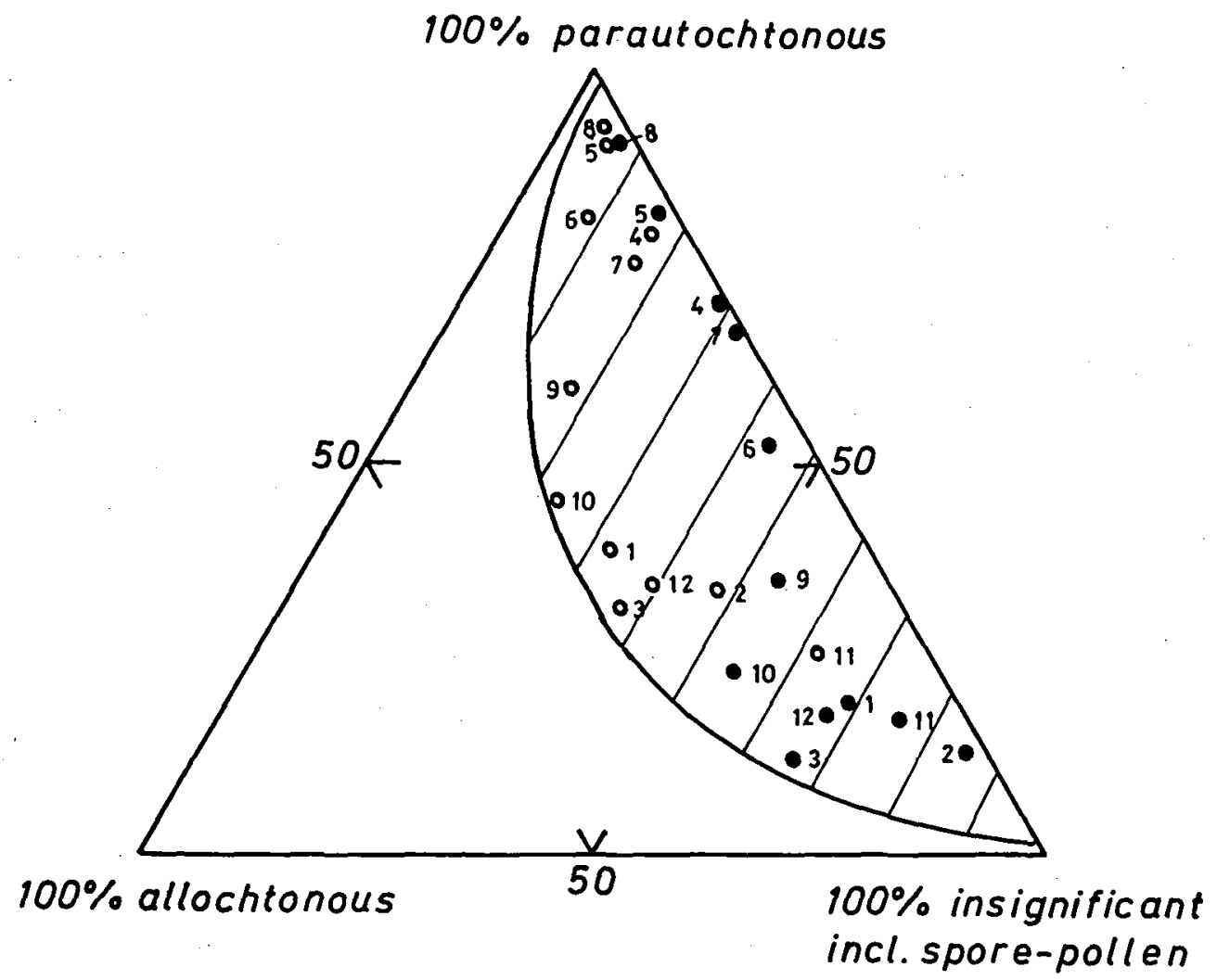

Fig. 2. Triangle-diagram showing the distribution of 1) allochtonous microplankton, 2) parautochtonous microplankton and 3) insignificant microplankton plus spore-pollen. Dots indicate the distribution before division of the insignificant group, circles after division of the insignificant group into the allochtonous and parautochtonous groups. Numbers refer to sample numbers. 
The insignificant group comprises long-ranging species, which cannot be assigned to any stratigraphic level mapped as one unit in the geological map of Denmark.

The present work is not sufficient for a statistically significant evaluation of the amount of allochtonous/parautochtonous matrix content in Danish glacial deposits. However, it appears from fig. 2 that a decrease in the parautochtonous microplankton content is related to an increase in spore-pollen content rather than to an increase in allochtonous microplankton.

Therefore, comparing the source-areas of the matrix with the source-areas of the clasts of Danish tills and tilloid deposits a discrepancy exists suggesting a more complex transportation of the clasts than of the matrix. It is well-known that the main part of clasts present in Danish tills are derived from the Fennoscandian Precambrian Shield, although Maastrichtian and Danian flints in some areas may dominate. The transportation ability of the inland-ice during the Quaternary has hardly been significantly different with reference to fine-grained and coarse-grained material, since both fine-grained and coarse-grained materials in Danish lodgement-tills are generally found to be an almost homogenous mixture (moraine-clay, boulder-clay, etc.). Consequently, it may be concluded that the clasts have been picked up together with the matrix-material by the ice far from the original source-area of the clasts. The clasts therefore must have been in the area from which the matrix originates before clasts and matrix were picked up and mixed together by the ice.

Thus, taking into account that the major part of the matrix-material could originate from the preQuaternary subground within a distance of less than $10 \mathrm{~km}$, it can be claimed that the coarser material has been transported during several cycles of reworking and deposition before the last deposition. This hypothesis is supported by studies of the stone-content in Danish tills (cf. Marcussen 1974 \& 1978, for references) and by studies on trace elements in the fine fraction (< $32 \mu \mathrm{m})$ from Danish tills. These trace elements show a clear affinity to the local pre-Quaternary subground (Binzer 1974).

\section{Dansk sammendrag}

12 prøver af danske istidsaflejringer er undersøgt for dinoflagellater, acritarcher, sporer $0 g$ pollen. Det vises, at hovedparten af dinoflagellaterne er oparbejdet fra den lokale undergrund. På basis af en tilnærmet stratigrafisk inddeling af mikroplanktonindholdet kan dette inddeles i bl.a. to grupper, hvoraf den ene og mest dominerende kan stamme fra undergrundslag inden for en afstand på mindre end $10 \mathrm{~km}$, mens den anden og mindste gruppe stammer fra undergrundslag mere end $10 \mathrm{~km}$ borte. Da hovedparten af sten i danske istidsaflejringer stammer fra det skandinaviske grundfjeld, kan der sảledes påvises en betydelig forskel i transportafstanden for istidsaflejringernes finkornede og grovkornede dele. Dette tages som udtryk for, at hovedparten af de grovkomede dele er transporteret i flere omgange, inden de nåede frem til stedet, hvor de ligger idag.

\section{References}

Andersen, S. Th. 1965: Pollen analysis and till stratigraphy at Lindø, Denmark. Geol. Soc. America. Inc. Spec. Paper, 84: 65-78.

Berthelsen, A. 1978: The methodology of kineto-stratigraphy as applied to glacial geology. Bull. Geol. Soc. Denmark, Special Issue, 27: 25-38.

Binzet, K. 1974: Sedimentological and geochemical features of Weichselian tills and pre-Quaternary sediments in Denmark. Geol. Survey Denmark, Yearbook 1973; 111-131.

Hansen, J. M. and Gudmundsson, L. in press: A method for separating acid-insoluble microfossils from organic debris. Micropaleontology 25 (2).

Marcussen, I. 1974: Stentællingsmetoden, ledeblokanalysen og glacialstratigrafi - en kritisk vurdering. Dansk geol. Foren. Arsskrift for 1973: 20-42.

Marcussen, I. 1978: Über die Verwandbarkeit von Geschieben in Grundmoränen als Hilfsmittel der Stratigraphie. Der Geschiebesammler, 12 (2/3): 13-20. 